\title{
Very cool white LED light improves reproductive performance and up-regulates expression of reproductive genes in layers
}

\author{
Hoda EL-EMAM ${ }^{1, a}$, Ahmed ATEYA ${ }^{1, b, \bowtie}$, Usama ABOU-ISMAIL $^{1, c}$, Iman EL-ARABY $^{2, d}$, \\ Mohamed FOUDA $^{1, e}$
}

\begin{abstract}
${ }^{1}$ Department of Husbandry and Development of Animal Wealth, Faculty of Veterinary Medicine, Mansoura University, Gomhoria St., Mansoura, Egypt; ${ }^{2}$ Department of Animal Wealth Development, Faculty of Veterinary Medicine, Zagazig University, Zagazig, Egypt

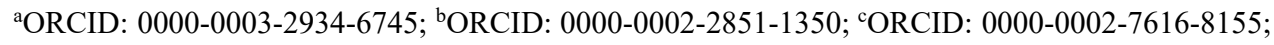
${ }^{\mathrm{d} O R C I D:}$ 0000-0003-1088-958X; 'ORCID: 0000-0002-5098-5333
\end{abstract}

Corresponding author: ahmed_ismail888@yahoo.com

Received date: 18.02.2021 - Accepted date: 18.08 .2021

\begin{abstract}
This study was carried out to evaluate the effect of light color temperature on reproductive performance and the expression pattern of GnRH-1 and FSH $\beta$ genes in layers. At lay, 165 Fayoumi healthy pullets were separated into well ventilated, environmentally controlled rooms. Birds were allocated into three groups with 55 birds each ( 5 males and 50 females) till 3 months after laying, representing base generation (F0). Fertile eggs were collected and incubated, and the newly hatched chicks were also divided into three groups from the first day of life till 3 months after laying, representing the first generation (F1). In the two generations, the first group was exposed to cool white LED light (day light) (6500 kelvin); the second group was exposed to very cool white LED light (sky blue light) (10000 kelvin); and the third group was exposed to warm white LED light (yellow light) (2700 kelvin). The expression profiles of GnRH-1 and FSH $\beta$ genes and the serum level of FSH were evaluated in birds of the two generations. Blue lightexposed groups exhibited better reproductive performance, higher up-regulation of GnRH-1 and FSH $\beta$ genes and increased FSH levels than those exposed to either the white or yellow light colors. A comparison between F0 and F1 revealed an improved profile for F1 birds. It therefore appears that blue LED light could improve the reproductive status of laying chickens.
\end{abstract}

Keywords: Gene expression, layer, light, reproductive performance.

\section{Introduction}

Poultry production is an important component of agriculture all over the world. Recently, more attention has been given to poultry, mainly due to the quality of their meat and sustainable production (24). Chickens provide more than 67.6 percent of the daily recommended value of protein, and more than 72 percent of the daily requirement for Niacin in a 4-ounce portion for an adult human (13). Eggs are also high in nutrition and protein and are a convenient, low-cost food. Eggs contain B12, riboflavin, and choline, which have been positively linked to the development of memory functions in fetuses. Meat from native chickens is preferred by more consumers than meat from commercial broilers due to their superior taste, meat texture, low fat and cholesterol, and high protein content (36).

Light is an important environmental factor for manipulating the behavioural activity (20), reproductive characteristics (5), growth performance (40) and immunity of birds. Light-emitting diodes (LED) are very energy efficient and hence provide sufficient brightness (22). Thus, most poultry producers have replaced ICD (inductively coupled discharges) lamps with LEDs. Moreover, LEDs are potentially beneficial to the poultry industry due to their long life span, moisture resistance, and narrow spectrum (31). An important aspect of light characters that could have an impact on an animal's productivity and reproduction is light color. Light color is described by chromaticity. Chromaticity is the measure of a light source's warmth (warm light) or coolness (cool light) expressed in degrees Kelvin. The scale runs from 2000 to $7000 \mathrm{~K}$. Light with chromaticity values of $4000 \mathrm{~K}$ or higher is considered cool (as blue light), light with chromaticity values of around $3500 \mathrm{~K}$ or $3600 \mathrm{~K}$ is called neutral, and light of about $3000 \mathrm{~K}$ or less is considered warm (as red light) (25).

Photoreceptors of the deep brain of birds are stimulated into action only by very specific colors of light. Light is received through retinal and extra-retinal 
photoreceptors. Photoreceptors are composed of large protein particles called opsins attached to an aldehyde of vitamin A, referred to as a chromophore (41). When a chromophore absorbs light, the photoreceptor goes through a conformational change, triggering a biochemical signal that is responsible for the release of neurotransmitters from the photoreceptor cell (16). Photoreceptors receive light signals and transmit them to oscillators, which control the bird's circadian rhythm via the synthesis and release of melatonin. The stimulation of photoreceptors is very important since it signals the production and release of certain hormones responsible for sexual development, aggressive behaviour and egg production (11).

GnRH1 is the gene that plays an important role in the generation of peptides responsible for the secretion of GnRH. GnRH1 is located on chromosome 8 (10). Gonadotropin-releasing hormone $(\mathrm{GnRH})$ is a neurohormone produced in a specific neural cell and released at its neural terminal (35). A key area for the production of GnRH is the preoptic area of the hypothalamus. GnRH neurons originate in the nose and migrate into the brain, where they are scattered throughout the medial septum and hypothalamus and connected by very long dendrites (7). GnRH plays a fundamental role in the release of gonadotropins from the pituitary gland and is considered the primary hormone that regulates reproduction (46).

The follicle-stimulating hormone (FSH) is another fundamental hormone for reproduction. FSH is a member of the glycoprotein hormones secreted by gonadotrophs in the anterior pituitary gland. It is comprised of two dissimilar subunits, alpha and beta, encoded by separate genes (14). FSH can stimulate the proliferation of granulosa cells (9) and is required for the long-term culture of granulosa cells. Moreover, FSH plays an important role in stimulating the release of progesterone (21). In chicken, the FSH $\beta$ precursor molecule consists of 131 amino acids with a signal peptide of 20 amino acids followed by a mature protein of 111 amino acids that is encoded by FSH $\beta$ cDNA, which is composed of 2,457 bp nucleotides, including 44-bp nucleotides of the 5'untranslated region (UTR), $396 \mathrm{bp}$ of the open reading frame, and a long $3^{\prime}$ - UTR of 2,001 bp nucleotides followed by a poly (A) tail (42).

Very few studies have considered how light color temperature could affect reproductive performance and the expression pattern of reproductive genes, particularly in laying chickens (15). Moreover, there is much controversy between the findings of literature regarding this. Therefore, the objective of the present study was to quantify the effects of different light color temperatures on reproductive performance traits, and the expression pattern of GnRH and FSH genes in native Egyptian Fayoumi layers (Gallus gallus domesticus).

\section{Materials and Methods \\ Experimental birds and design}

Base generation $\left(F_{0}\right)$ : One hundred sixty-five native Egyptian Fayoumi healthy pullets at 17 weeks of age with similar body weight $(900 \pm 30$ gram) were used in this experiment. Pullets were purchased from an experimental farm for poultry breeding in Fayoum Governorate, Egypt. All birds were housed under the same environment till the time of laying at a density of $8 \mathrm{birds} / \mathrm{m}^{2}, 12 \mathrm{~L}$ : 12D light cycle, $67-77 \% \mathrm{RH}$, and $28{ }^{\circ} \mathrm{C}$. From the $19^{\text {th }}$ week the lighting schedule was gradually increased half an hour every week till it reached 16L: $8 \mathrm{D}$ at laying time. At laying, $24^{\text {th }}$ weeks, birds were randomly assigned into three groups of 55 birds each, in separate, well-ventilated, environmentally controlled rooms according to the light color temperature. Each room had a floor area of $9 \mathrm{~m}^{2}$ and was used for housing 50 females and 5 males. The first group (control) was exposed to cool LED white light (daylight) (6500 kelvin). The second group (sky blue light) was exposed to very cool LED white light (10000 kelvin) and the third group (yellow light) was exposed to warm LED white light (2700 kelvin) till the end of the experiment. Light intensity was $25 \mathrm{~lx}$ (1.4-ft candle) during light phase and $0 \mathrm{~lx}$ during dark phase of the photoperiod and was recorded near the floor, approximately at the bird's height. Artificial light systems were placed $10 \mathrm{~cm}$ above the birds using plastic crosses attached to the ceilings of the rooms. Food and drinking water were allowed ad-libitum throughout the experimental period.

First generation $\left(\boldsymbol{F}_{1}\right)$ : Eggs were collected daily, and egg numbers and egg weights were recorded daily for each group. Eggs were incubated at $37{ }^{\circ} \mathrm{C}$ and $70 \% \mathrm{RH}$, and the newly hatched chicks $\left(\mathrm{F}_{1}\right)$ were marked using wing bands. Chicks were vaccinated using the program of vaccination of the Local Veterinary Organization. Equal number of chicks to that of $F_{0}$ was selected and used for the $F_{1}$ generation. Chicks were divided into three groups of 55 birds each ( 5 males and 50 females) from the first day of life similar to those of the base generation; control cool white, very cool sky-blue light and warm yellow light but were subjected to continuous artificial lighting during the first 8 weeks of age. This artificial light was decreased to 12 hours light and 12 hours dark in $17^{\text {th }}$ week of age, then was gradually increased one hour/month till reached 16 hours light at the $21^{\text {st }}$ week of age.

Reproductive performance traits: Fertility $\%$ and hatchability $\%$ were estimated according to the method described previously (32).

- Fertility percentage $\%(\mathrm{~F} \%)=($ No of fertile eggs/total No of eggs set) x 100.

- Hatchability $\%=($ No of hatched chicks/total No of fertile eggs) x 100 . 
Egg number and egg weight were estimated weekly for each group as per a previously described method (43). EW was recorded by weighing all eggs of each group using an electric digital balance with a range from 0.1 to 200 g. The mean egg number per hen was calculated by dividing total egg number of eggs per group by number of birds. Mean egg weight was calculated by dividing the total egg weight per hen per week by the number of eggs per hen per week (19). Eggs were weighed individually and recorded to the nearest $0.1 \mathrm{~g}$ using an electric digital balance with a range from 0.1 to $200 \mathrm{~g}$. Egg length and egg width were measured using a Vernier caliper by carefully placing the internal content of an egg on a smooth glass plate to avoid rupture of the vitelline membrane. Egg shape index was calculated as egg width percent divided by length percent according to (2). Albumen weight was measured and recorded to the nearest $0.1 \mathrm{~g}$ using an electric digital balance. Albumen height was measured by placing a tripod at different places of thick albumen and an average of three readings was considered as albumen height. Haugh units \% (HU \%) were estimated according to a previous method (18).

$\mathrm{HU}=100 \log \left(\mathrm{H}+7.57-1.7 \mathrm{~W}^{0.37}\right)$ where; HU = Haugh units, $\mathrm{H}=$ albumen height $(\mathrm{mm})$ and $\mathrm{W}=$ egg weight in gram.

Yolk weight was measured and recorded to the nearest $0.1 \mathrm{~g}$ using an electric digital balance. Yolk index $\%=$ yolk height /yolk diameter (12). Shell weight was measured and recorded to the nearest $0.1 \mathrm{~g}$ using an electric digital balance. Shell thickness (mm) was measured in micrometers as an average of 3 points (top, medial and base).
Sample collection: In both $F_{0}$ and $F_{1}$, tissue and blood samples were taken from all female and male birds. Tissue samples were taken from the hypothalamus and pituitary gland for RNA extraction. Samples were put in Eppendorf containing RNA later (Qiagen, Germany), to minimize the action of endogenous Rnase. Blood samples were collected without anticoagulant from wing veins into clean dry centrifuge tubes, were left to clot at room temperature and were then centrifuged at $3000 \mathrm{rpm}$ for 15 min. Serum was stored at $-20{ }^{\circ} \mathrm{C}$ until biochemical analysis.

RNA extraction and real-time PCR: RNA extraction was done using Rneasy Mini Kit (Qiagen, Germany), following the manufacturer protocol. RNA was treated with RNAse free-DNAse I (Qiagen, Germany), to remove any contaminating genomic DNA. The expression profile of GnRH and FSH genes was carried out in hypothalamus and pituitary gland respectively. The relative expression was quantified using SYBR Green PCR Master Mix (2xSensiFast ${ }^{\mathrm{TM}}$ SYBR, Bioline) and carried out according to primers described previously (49). Primer sequences and annealing temperatures are shown in Table 1 . The housekeeping $\beta$ actin gene was used as an internal control. Reverse transcription of extracted mRNA and real-time PCR program schedule for each gene is illustrated in Table 2. CT values were determined by stratagene MX3005P software. To estimate the variation of gene expression in RNA of different samples, CT of each sample was compared with that of the control group according to the " $\Delta \Delta \mathrm{Ct}$ " method (49).

Table 1. Oligonucleotide primers sequence, accession number, annealing temperature and PCR product size of GnRH-I, FSH- $\beta$ and $\beta$ Actin genes.

\begin{tabular}{llccc}
\hline Gene & Primer (forward) & Product length (bp) & Accession number & Reference \\
\hline \multirow{2}{*}{ GnRH-I } & F:5-ATCTGCTTGGCTCAACACTG-3 & 191 & NM_001080877.1 & $(15)$ \\
& R: 5-ATCAGGCTTGCCATGGTTTC-3 & & & $(15)$ \\
FSH- $\beta$ & F:5-GCCATCCTACTGCTCCTTCA-3 & 154 & NM_204257.1 \\
& R:5-GCTTGGCAGTTTCTCGGTAC-3 & & \\
$\beta$ - sctin & F:5-GAGAAATTGTGCGTGACATCA-3 & R:5-CCTGAACCTCTCATTGCCA-3 & 152 & NM_205518.1
\end{tabular}

Table 2. Reverse transcription and real-time PCR program for GnRH-I, FSH- $\beta$ and $\beta$-Actin genes.

\begin{tabular}{|c|c|c|c|c|c|c|c|c|}
\hline \multirow{2}{*}{ Gene } & \multirow{2}{*}{$\begin{array}{l}\text { Reverse } \\
\text { transcription }\end{array}$} & \multirow{2}{*}{$\begin{array}{l}\text { Primary } \\
\text { denaturation }\end{array}$} & \multicolumn{3}{|c|}{ Amplification (40 cycles) } & \multicolumn{3}{|c|}{$\begin{array}{l}\text { Dissociation curve } \\
\text { (1 cycle) }\end{array}$} \\
\hline & & & $\begin{array}{l}\text { Secondary } \\
\text { denaturation }\end{array}$ & Annealing & Extension & $\begin{array}{l}\text { Secondary } \\
\text { denaturation }\end{array}$ & Annealing & $\begin{array}{l}\text { Final } \\
\text { extension }\end{array}$ \\
\hline GnRH-1 & $50^{\circ} \mathrm{C}$ & $94^{\circ} \mathrm{C}$ & $94^{\circ} \mathrm{C}$ & $60^{\circ} \mathrm{C}$ & $72^{\circ} \mathrm{C}$ & $94^{\circ} \mathrm{C}$ & $60^{\circ} \mathrm{C}$ & $72^{\circ} \mathrm{C}$ \\
\hline$F S H-\beta$ & $30 \mathrm{~min}$. & $15 \mathrm{~min}$. & $15 \mathrm{sec}$. & $30 \mathrm{sec}$. & $30 \mathrm{sec}$. & $1 \mathrm{~min}$. & $1 \mathrm{~min}$. & $1 \mathrm{~min}$ \\
\hline \multirow{2}{*}{ ß.actin } & $50^{\circ} \mathrm{C}$ & $94^{\circ} \mathrm{C}$ & $94^{\circ} \mathrm{C}$ & $51^{\circ} \mathrm{C}$ & $72^{\circ} \mathrm{C}$ & $94^{\circ} \mathrm{C}$ & $51^{\circ} \mathrm{C}$ & $72^{\circ} \mathrm{C}$ \\
\hline & $30 \mathrm{~min}$. & $15 \mathrm{~min}$. & $15 \mathrm{sec}$. & $30 \mathrm{sec}$. & $30 \mathrm{sec}$. & $1 \mathrm{~min}$. & $1 \mathrm{~min}$. & $1 \mathrm{~min}$. \\
\hline
\end{tabular}




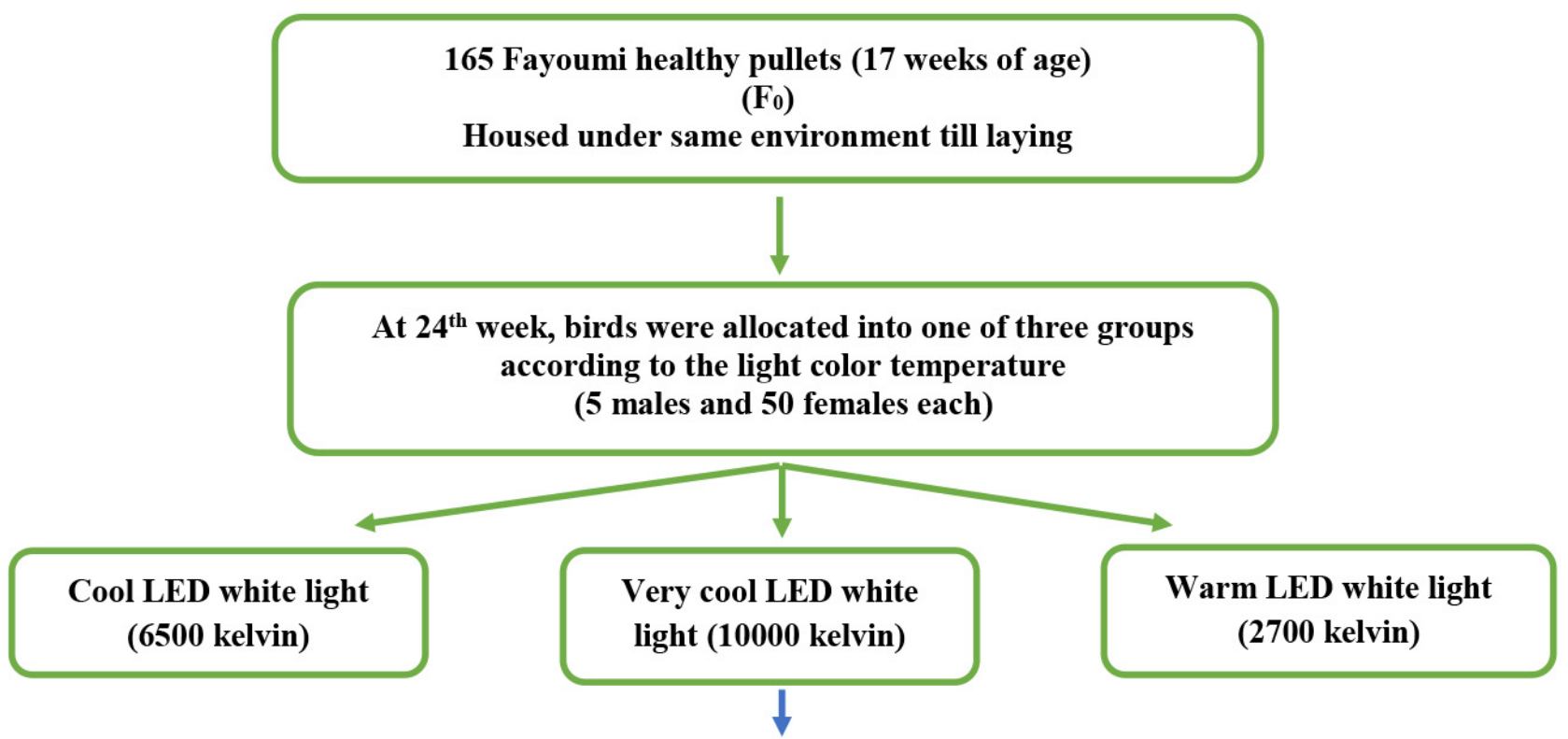

Figure 1. Experimental design, measures and samples collected from both male and female birds of base $\left(\mathrm{F}_{0}\right)$ and first $\left(\mathrm{F}_{1}\right)$ generation throughout the study.

Biochemical analysis: Serum values of FSH were determined according to the Siemens health diagnostics USA kits protocol as previously described (3). The producer depends on using IMMULITE/IMMULITE 2000 rapid FSH, which is a solid-phase, enzyme labelled chemiluminescent immunometric assay. Experimental design, measures and samples collected from birds of both $F_{0}$ and $F_{1}$ throughout the study period are presented in Figure 1.

Data analysis: Data were tested for distribution normality, linearity and homogeneity of variance. Data were analysed using SPSS (Statistical Package for Social Science) version 12 and all results are reported as means \pm SEM. Analysis of egg number, egg weight, egg mass, fertility $\%$, hatchability $\%$ and egg quality traits were performed using General Linear Model (GLM) procedures-repeated measures. Remaining data were analysed using one-way analysis of variance (ANOVA) to test all groups unpaired values. Duncan Multiple Range Test was used to separate means among the treatment groups. Differences were considered to be significant at the level of $(\mathrm{P} \leq 0.05)$.

\section{Results}

Effect of light color temperature on reproductive traits: Females of base $\left(\mathrm{F}_{0}\right)$ and first $\left(\mathrm{F}_{1}\right)$ generations under different color light temperatures were evaluated for the following traits; egg number, egg weight, egg mass, fertility $\%$, hatchability $\%$, and egg quality traits including; egg shape index \% (ESI), albumen weight, Haugh unit, yolk weight, yolk index \%, shell weight and shell thickness (Table 3). Birds of blue light-exposed group exhibited a better performance for all reproductive traits compared to those of white light and yellow lightexposed groups. Comparison between $F_{0}$ and $F_{1}$ revealed that females of $F_{1}$ had a better reproductive performance than those of $\mathrm{F}_{0}$.

Effect of light color temperature on expression pattern of reproductive genes: The effect of light color temperature on expression pattern of reproductive genes $(G n R H-1$ and FSH $\beta)$ was investigated in both males and females of $F_{0}$ and $F_{1}$ (Figure 2). Blue color light-exposed groups exhibited a significant up-regulation of FSH $\beta$ and $G n R H-1$ in both males and females compared to white (control) and yellow color light-exposed groups. Comparison of $\mathrm{F}_{0}$ and $\mathrm{F}_{1}$ generations demonstrated that $\mathrm{F}_{1}$ had a higher up-regulation of FSH $\beta$ and $G n R H-1$ genes than $\mathrm{F}_{0}$ in both males and females.

Effect of light color temperature on serum biochemical analysis: The effect of light color temperature on serum profile of FSH was explored in both males and females of $F_{0}$ and $F_{1}$ (Figure 3). Blue color light-exposed groups exhibited a significant increase in serum FSH values in both males and females compared to white (control) and yellow color light-exposed groups. Comparison of $F_{0}$ and $F_{1}$ generations elucidated that $F_{1}$ generation had higher values of FSH than $\mathrm{F}_{0}$ in both males and females. 
Table 3. Mean ( \pm SE mean) reproductive performance parameters of female Fayoumi layers reared under monochromatic cool white (Control), very cool white (Blue sky), warm white light (Yellow) at base $\left(\mathrm{F}_{0}\right)$ and first $\left(\mathrm{F}_{1}\right)$ generation.

\begin{tabular}{|c|c|c|c|c|c|c|}
\hline \multirow{3}{*}{$\begin{array}{l}\text { Group } \\
\text { Traits }\end{array}$} & \multicolumn{2}{|c|}{ Cool white (Control) } & \multicolumn{2}{|c|}{ Very cool white (Blue sky) } & \multicolumn{2}{|c|}{ Warm white (Yellow) } \\
\hline & $\mathbf{F}_{0}$ & $\mathbf{F}_{1}$ & $\mathbf{F}_{0}$ & $\mathbf{F}_{1}$ & $\mathbf{F}_{0}$ & $\mathbf{F}_{1}$ \\
\hline & \multicolumn{6}{|l|}{ Means \pm SE } \\
\hline Egg number & $1.97^{\mathrm{bB}} \pm 0.32$ & $3.88^{\mathrm{bA}} \pm 0.18$ & $4.82^{\mathrm{aA}} \pm 0.54$ & $4.93^{\mathrm{aA}} \pm 0.15$ & $2.26^{\mathrm{bB}} \pm 0.37$ & $3.94^{\mathrm{bA}} \pm 0.26$ \\
\hline Egg weight & $36.58^{\mathrm{aB}} \pm 0.42$ & $51.7^{\mathrm{aA}} \pm 0.10$ & $37.84^{\mathrm{aB}} \pm 0.19$ & $55.1^{\mathrm{aA}} \pm 0.06$ & $37.94^{\mathrm{aB}} \pm 0.45$ & $42.3^{\mathrm{bA}} \pm 0.04$ \\
\hline Egg mass $(g)$ & $72.06^{\mathrm{cB}} \pm 0.40$ & $200.59^{\mathrm{bA}} \pm 0.09$ & $182.33^{\mathrm{aB}} \pm 0.23$ & $271.60^{\mathrm{aA}} \pm 0.32$ & $85.74^{\mathrm{bB}} \pm 0.25$ & $166.66^{\mathrm{cA}} \pm 0.13$ \\
\hline Fertility \% & $87.00^{\mathrm{bA}} \pm 0.57$ & $89.9^{\mathrm{bA}} \pm 0.66$ & $98.87^{\mathrm{aA}} \pm 0.53$ & $100.00^{\mathrm{aA}} \pm 0.66$ & $90.06^{\mathrm{bA}} \pm 0.50$ & $93.3^{\mathrm{bA}} \pm 0.60$ \\
\hline Hatchability \% & $92.6^{\mathrm{bA}} \pm 0.15$ & $93.03^{\mathrm{bA}} \pm 0.70$ & $99.00^{\mathrm{aA}} \pm 0.09$ & $100.00^{\mathrm{aA}} \pm 0.55$ & $97.33^{\mathrm{aA}} \pm 0.40$ & $98.76^{\mathrm{aA}} \pm 0.55$ \\
\hline Egg shape index \% (ESI) & $76.85^{\mathrm{aA}} \pm 0.82$ & $76.65^{\mathrm{aA}} \pm 0.37$ & $74.14^{\mathrm{aB}} \pm 0.36$ & $75.00^{\mathrm{aA}} \pm 0.24$ & $75.14^{\mathrm{aA}} \pm 0.55$ & $76.40^{\mathrm{aA}} \pm 0.86$ \\
\hline Albumen weight (g) & $21.00^{\mathrm{bA}} \pm 0.87$ & $22.00^{\mathrm{bA}} \pm 0.82$ & $21.14^{\mathrm{bA}} \pm 0.40$ & $22.13^{\mathrm{bA}} \pm 0.49$ & $25.56^{\mathrm{aA}} \pm 0.56$ & $26.56^{\mathrm{aA}} \pm 0.68$ \\
\hline Haugh unite \% (HU) & $81.91^{\mathrm{abA}} \pm 0.22$ & $82.91^{\mathrm{abA}} \pm 0.22$ & $84.75^{\mathrm{aA}} \pm 0.23$ & $85.75^{\mathrm{aA}} \pm 0.23$ & $81.14^{\mathrm{bA}} \pm 0.60$ & $81.64^{\mathrm{bA}} \pm 0.39$ \\
\hline Yolk weight (g) & $15.57^{\mathrm{aA}} \pm 0.47$ & $16.57^{\mathrm{aA}} \pm 0.34$ & $15.42^{\mathrm{aA}} \pm 0.75$ & $15.80^{\mathrm{aA}} \pm 0.75$ & $14.42^{\mathrm{aA}} \pm 0.49$ & $15.42^{\mathrm{aA}} \pm 0.42$ \\
\hline Yolk index \% & $49.00^{\mathrm{aA}} \pm 0.75$ & $49.80^{\mathrm{aA}} \pm 0.56$ & $52.85^{\mathrm{aA}} \pm 0.75$ & $52.80^{\mathrm{aA}} \pm .57$ & $51.85^{\mathrm{aA}} \pm 0.68$ & $50.85^{\mathrm{aA}} \pm 0.56$ \\
\hline Shell weight (g) & $6.14^{\mathrm{aA}} \pm 0.34$ & $6.05^{\mathrm{aA}} \pm 0.27$ & $6.57^{\mathrm{aA}} \pm 0.20$ & $6.90^{\mathrm{aA}} \pm 0.30$ & $5.00^{\mathrm{bA}} \pm 0.20$ & $5.00^{\mathrm{bA}} \pm 0.30$ \\
\hline Shell thickness (mm) & $1.00^{\mathrm{bA}} \pm 0.10$ & $1.00^{\mathrm{bA}} \pm 0.10$ & $1.42^{\mathrm{aA}} \pm 0.20$ & $1.50^{\mathrm{aA}} \pm 0.20$ & $1.00^{\mathrm{bA}} \pm 0.23$ & $1.00^{\mathrm{bA}} \pm 0.60$ \\
\hline
\end{tabular}

Means of different levels within the same column having different superscripts are significantly different $(\mathrm{P}<0.05)$. Small letter indicates a significant difference between groups at the same generation. Capital letter indicates a significant difference between generations.

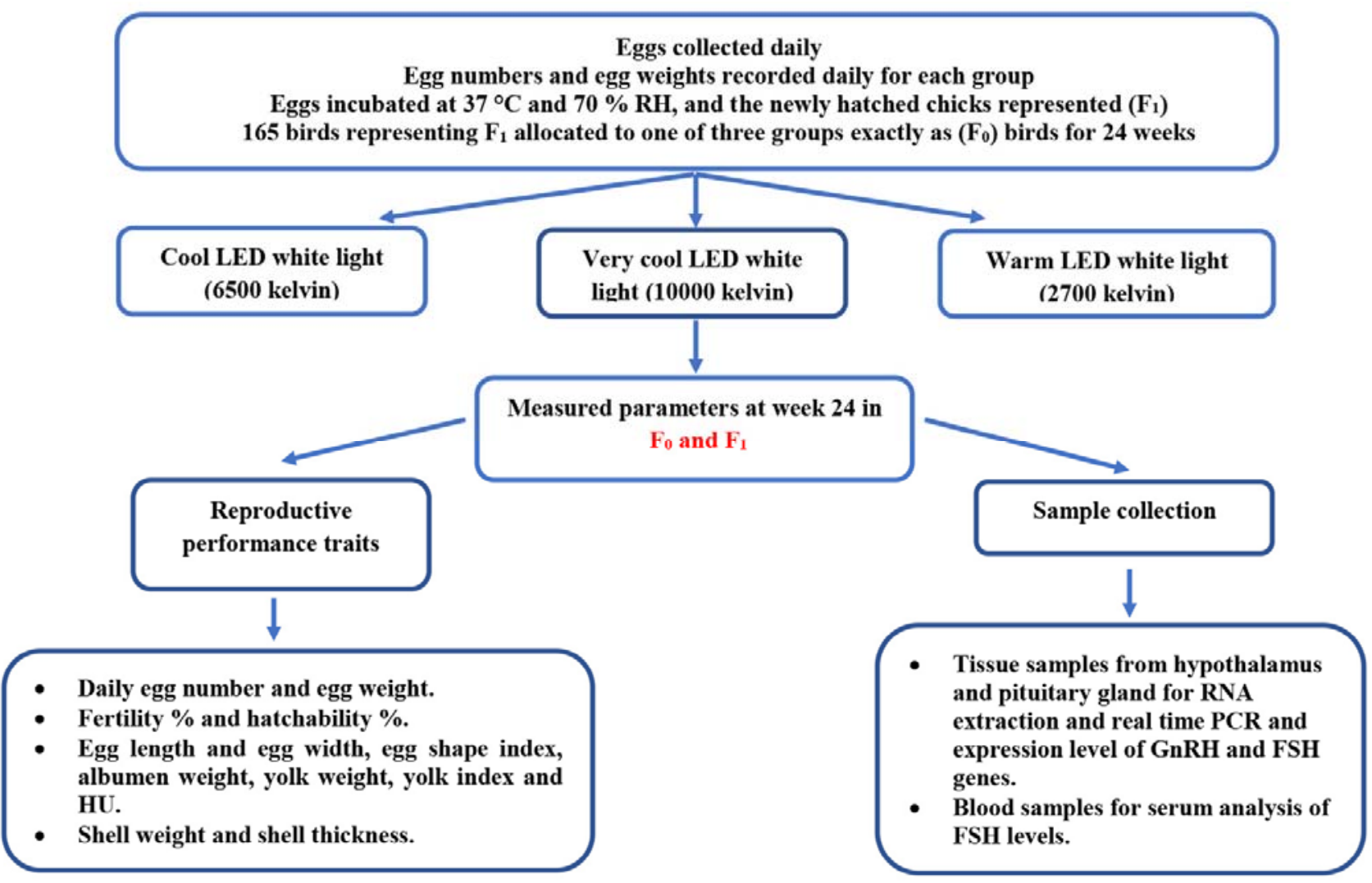

Figure 2. Relative expression of $F S H \beta$ (a) and $G n R H 1$ (b) in both males and females of base $\left(\mathrm{F}_{0}\right)$ and first $\left(\mathrm{F}_{1}\right)$ generation. Small letter indicates a significant difference $(\mathrm{P}<0.05)$ between groups at the same generation. Capital letter indicates a significant difference $(\mathrm{P}<0.05)$ between generations. 

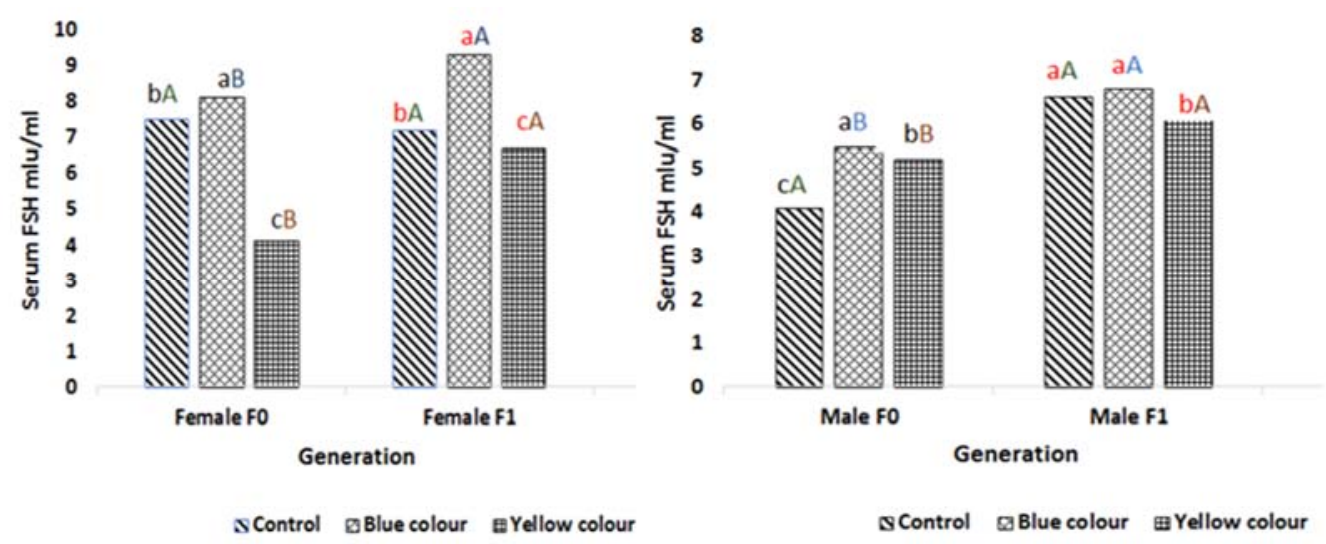

Figure 3. Serum levels of FSH in both males and females of base $\left(\mathrm{F}_{0}\right)$ and first $\left(\mathrm{F}_{1}\right)$ generation. Small letter indicates a significant difference $(\mathrm{P}<0.05)$ between groups at the same generation. Capital letter indicates a significant difference $(\mathrm{P}<0.05)$ between generations.

\section{Discussion and Conclusion}

Poultry has a major role to play in developing countries because it is relatively inexpensive and widely available. Chickens are the most popular poultry worldwide irrespective of culture and religion (1). This is because poultry products have a very high nutritive value and a low detrimental impact on the environment than other livestock and uses less water (44). Layers have been submitted to genetic improvement to produce more eggs at lighter body weight and with a lower feed intake. So, layer farms need to supply high nutritional requirements of birds and to apply management practices that can adapt to automated and environmentally controlled facilities, and high stocking densities (33). In the current study, the effects of light color temperature on the reproductive performance traits were investigated in $\mathrm{F}_{0}$ and $\mathrm{F}_{1}$ Fayoumi layers. The results of this study showed that very cool LED light improves reproductive performance traits of laying hens, serum FSH levels and up-regulation of mRNA level of GnRH-1 and FSH $\beta$ genes. The effects of light on reproductive performance may be related to the wavelength of light. One reason for the improved reproductive performance of birds experienced blue LED color could be their improved behaviour and temperament e.g., calming effect of the blue light perse. It has been demonstrated that birds reared under blue LED light were less active, less aggressive, less fearful and more docile compared to those reared under other light color environments (30). This reduced level of activity and fear might have redirected energy expenditure towards efficient reproductive traits. This could be supported by the fact that chickens demonstrated higher preferences for both blue and green light than for red and white light (34). However, the improved reproductive performance of laying chickens reared in monochromatic blue LED light could be also due to the increased estradiol and progesterone levels, and the decreased levels of melatonin hormone. It has been shown that blue light decreased plasma concentrations of melatonin, and increased plasma concentrations of estradiol and progesterone at $28 \mathrm{wk}$. of age in Erlang Mountainous Chinese laying hens (27). It could also be due to the up-regulated expression of reproductive genes and the increased serum levels of FSH as illustrated in our findings.

Findings of previous studies that investigated the effects of light color temperature on reproductive performance of chickens demonstrated controversial results. On one hand, some experiments concluded chicken who experienced blue color light demonstrated improved reproductive performance compared to those who received either white or yellow color light. Improved reproductive performance due to blue light included higher egg weights (17), higher levels of egg production $(27,28)$, and extended peak laying (27). On the other hand, other experiments showed that reproductive performance of birds represented by higher egg numbers was improved when birds were reared in red color light compared to other colors of lights (47). Other research has given the advantage of improving reproductive performance e.g., fertility and hatchability to white light rather than red, yellow or green (48). However, other studies observed no differences in productive performance of chicken e.g., egg weights and egg numbers (26), or fertility and hatchability (8) under different color lights. Others have reported that egg weight depended particularly on hen's age and nutritional factors rather than on light color (6). One reason for the controversy between results reported in the current experiment and those of previous work could be differences in light source, light color temperature, species/strain of birds, light intensity, and number of generations of birds investigated.

Results of the current experiment demonstrated also that very cool white LED (blue) light up-regulated $G n R H$ 1 and $F S H \beta$ gene expression in both males and females of $\mathrm{F}_{0}$ and $\mathrm{F}_{1}$. To the best of our knowledge, the effect of light color on the expression pattern of reproductive genes in 
layers has received little investigation. However, beneficial effects have been attached to the blue monochromatic LED light on reproductive traits and expression patterns of estradiol (ER $\alpha$ and ER $\beta$ ) mRNA and progesterone mRNA in granulosa layers (27). Extraretinal photo-stimulation combined with non-photostimulatory conditions to the retina caused a significant elevation in mRNA expression of hypothalamic GnRH-I, pituitary LH and FSH, plasma LH and gonadal steroids in broiler breeders (38). Similarly, GnRH-I mRNA expression in female turkey was sensitive to light stimulation during the photosensitive period (23) and was therefore used to characterize their different reproductive stages.

On the other hands, other experiments, despite lacking blue LED light in its lighting schedule, have reported a higher hypothalamic GnRH-I mRNA expression was observed in birds under red light had than those exposed to green light in white leghorn birds and broiler breeder hens (Cobb) respectively (29, 37). However, light source was not found to impact gene expression of $G n R H-I$ and $F S H-\beta$ in chickens (4).

Results of the current study also indicated that very cool white LED light (blue) elevated serum levels of FSH in both males and females of $F_{0}$ and $F_{1}$. This increase in FSH levels could be a reflection to the increased expression level of GnRH-1 and FSH $\beta$ gene. However, it could have also resulted as a reflection to the increased levels of estradiol and progesterone, and the upregulated expression patterns of estradiol and progesterone mRNA. Similar findings of increased serum FSH under monochromatic blue LED light have been previously demonstrated $(26,39,45)$.

Light color temperature has a remarkable effect on reproductive performance of laying chickens particularly Egyptian Fayoumi layers. Blue LED light improved bird reproductive performances via increasing reproductive performance traits, serum FSH levels and up-regulation of mRNA level of reproduction-related genes. These findings recommend blue LED light in farms of layer chicken to improve their reproductive performance. Further studies should be carried out to investigate the effects of light color temperature on other chicken breeds. An expression profile of other reproductive genes is also needed to understand their regulation mechanisms on other productive and reproductive traits.

\section{Acknowledgements}

The authors acknowledge members of Department of Husbandry and Development of Animal Wealth, Faculty of Veterinary Medicine, Mansoura University, for their valuable advice and cooperation.

\section{Financial Support}

The author(s) received no financial support for the research, authorship, and/or publication of this article.

\section{Ethical Statement}

The collection of samples and care of birds used in this study followed guidelines of Mansoura University and the protocol of the study and the protocol of the study was approved by the Research Ethics Committee, Faculty of Veterinary Medicine, Mansoura University.

\section{Conflict of Interest}

The authors declare no conflicts of interest.

\section{References}

1. Al-Nasser A, Al-Khalaifa H, Al-Saffar A, et al (2007): Overview of chicken taxonomy and domestication. World Poultry Sci J, 63, 285-300.

2. Anderson K, Tharrington J, Curtis P, et al (2004): Shell characteristics of eggs from historic strains of single comb white leghorn chickens and the relationship of egg shape to shell strength. Int J Poult Sci, 3, 17-19.

3. Baloch Z, Carayon P, Conte-devolx B, et al (2003): Laboratory medicine practice guidelines. Laboratory support for the diagnosis and monitoring of thyroid disease. Thyroid, 13, 3-126.

4. Baxter M, Joseph N, Osborne V, et al (2014): Red light is necessary to activate the reproductive axis in chickens independently of the retina of the eye. Poult Sci, 93, 1289-1297.

5. Bobadilla-Mendez M, Rojas-Granados C, Andrade E, et al (2016): Effect of different light sources on reproductive anatomy and physiology of Japanese quail (Coturnix coturnix japonica). Anim Reprod Sci, 168, 50-56.

6. Borille R, Garcia R, Royer A, et al (2013): The use of light-emitting diodes (LED) in commercial layer production. Braz J Poult Sci, 15, 135-140.

7. Campbell RE, Gaidamaka G, Han S-K, et al (2009): Dendro-dendritic bundling and shared synapses between gonadotropin-releasing hormone neurons. Proc Nat Acad Sci, 106, 10835-10840.

8. Chang S, Lin M, Zhuang Z, et al (2016): Effect of monochromic light-emitting diode light with different color on the growth and reproductive performances of breeder geese. Asian Austral J Anim, 29, 830-837.

9. Davis AJ, Brooks CF, Johnson PA (2001): Folliclestimulating hormone regulation of inhibin $\alpha$-and $\beta B$-subunit and follistatin messenger ribonucleic acid in cultured avian granulosa cells. Biol Reprod, 64, 100-106.

10. Dungan HM, Clifton DK, Steiner RA (2006): Kisspeptin neurons as central processors in the regulation of gonadotropin-releasing hormone secretion. Endocrinology, 147, 1154-1158.

11. El Halawani M (2013): Light spectrum requirement for maximizing breeder hen turkey egg production. Gobbles, 70, 6-8.

12. El-Tarabany M (2002): Factors affecting egg production patterns in some commercial layer flocks. M.V.Sc, Faculty of Veterinary Medicine, Zagazig University, Egypt.

13. Farrell D (2013): The Role of Poultry in Human Nutrition, 2. Available at: http://www.fao.org/docrep/013/al712e/ al712e00.pdf. Accessed on: 1 July 2015.

14. Gharib SD, Roy A, Wierman ME, et al (1989): Isolation and characterization of the gene encoding the $\beta$-subunit of rat follicle-stimulating hormone. DNA, 8, 339-349. 
15. Han S, Wang Y, Liu L, et al (2017): Influence of three lighting regimes during ten weeks growth phase on laying performance, plasma levels-and tissue specific gene expression-of reproductive hormones in Pengxian yellow pullets. PloS One, 12, e0177358.

16. Hartl FU, Hayer-Hartl M (2002): Molecular chaperones in the cytosol: from nascent chain to folded protein. Science, 295, 1852-1858.

17. Hassan R, Sultana S, Choe HS, et al (2013): Effect of Monochromatic and Combined Light Color on Performance, Blood Parameters, Ovarian Morphology and Reproductive Hormones in Laying Hens. Ital J Anim Sci, 12, 359-364.

18. Haugh R (1937): The Haugh unit for measuring egg quality. U.S. egg \& poultry magazine, $\mathbf{4 3}, 522-555$.

19. Hoyt DF (1979): Practical methods of estimating volume and fresh weight of bird eggs. The Auk, 96, 73-77.

20. Huber-Eicher B, Suter A, Spring-Stähli P (2013): Effects of colored light-emitting diode illumination on behavior and performance of laying hens. Poult Sci, 92, 869-873.

21. Johnson AL, Solovieva E, Bridgham J (2002): Relationship between steroidogenic acute regulatory protein expression and progesterone production in hen granulosa cells during follicle development. Biol Reprod, 67, 1313-1320.

22. Kamanli S, Durmus I, Demir S, et al (2015): Effect of different light sources on performance and egg quality traits in laying hens. Eur Poult Sci, 79, 1-10.

23. Kang SW, Thayananuphat A, Rozenboim I, et al (2006): Expression of hypothalamic GnRH-I mRNA in the female turkey at different reproductive states and following photostimulation. Gen Comp Endocrinol, 146, 91-99.

24. Kaya M, Yildiz MA (2008): Genetic diversity among Turkish native chickens, Denizli and Gerze, estimated by microsatellite markers. Biochem Genet, 46, 480-491.

25. Knisley JR (1990): Updating light sources for new and existing facilities. EC\&M, 89, 49-60.

26. Li D, Zhang L, Yang M, et al (2014): The effect of monochromatic light-emitting diode light on reproductive traits of laying hens. J Appl Poult Res, 23, 367-375.

27. Liu L, Li D, Gilbert ER, et al (2015): Effect of Monochromatic Light on Expression of Estrogen Receptor (ER) and Progesterone Receptor (PR) in Ovarian Follicles of Chicken. PLoS One, 10, e0144102.

28. Mobarkey N, Avital N, Heiblum R, et al (2010): The role of retinal and extra-retinal photostimulation in reproductive activity in broiler breeder hens. Domest Anim Endocrinol, 38, 235-243.

29. Mobarkey N, Avital N, Heiblum R, et al (2013): The effect of parachlorophenylalanine and active immunization against vasoactive intestinal peptide on reproductive activities of broiler breeder hens photostimulated with green light. Biol Reprod, 88, 81-87.

30. Mohamed RA, Abou-Ismail UA, Shukry MC (2016): Effects of different monochromatic LED light colors on fear reactions and physiological responses in Mulard ducks. Anim Prod Sci, 57, 1128-1136.

31. Olanrewaju H, Purswell J, Maslin W, et al (2015): Effects of color temperatures (kelvin) of LED bulbs on growth performance, carcass characteristics, and ocular development indices of broilers grown to heavy weights. Poult Sci, 94, 338-344.
32. Ozcelik M, Cerit H, Ekmen F, et al (2006): Effect of the hatching month as an environmental factor on the hatching features of bronze turkeys. Turk J Vet Anim Sci, 30, 243-249.

33. Pavan A, Garcia E, Mori C, et al (2005): Effect of cage stocking density on performance of laying hens during the growing and laying periods. Rev Bras Zootecn, 34, 1320-1328.

34. Prayitno DS, Philips CJ, Stokes DK (1997): The effects of color intensity of light on behavior and leg disorders in broiler chickens. Poult Sci, 76, 1674-1681.

35. Prevot V, Bellefontaine N, Baroncini M, et al (2010): Gonadotrophin-releasing hormone nerve terminals, tanycytes and neurohaemal junction remodelling in the adult median eminence: functional consequences for reproduction and dynamic role of vascular endothelial cells. J Neuroendocrinol, 22, 639-649.

36. Promwatee N, Laopaiboon B, Vongpralub $T$, et al (2013): Insulin-like growth factor I gene polymorphism associated with growth and carcass traits in Thai synthetic chickens. Genet Mol Res, 12, 4332-4341.

37. Reddy IJ, David CG, Selvaraju S, et al (2012): GnRH-1 $m R N A$, LH surges, steroid hormones, egg production, and intersequence pause days alter in birds exposed to longer wavelength of light in the later stages of production in Gallus gallus domesticus. Trop Anim Health Prod, 44, 1311-1317.

38. Rozenboim I, Biran I, Uni Z, et al (1999): The effect of monochromatic light on broiler growth and development. Poult Sci, 78, 135-138.

39. Rozenboim I, El Halawani M, Kashash Y, et al (2013): The effect of monochromatic photostimulation on growth and development of broiler birds. Gen Comp Endocrinol, 190, 214-219.

40. Rozenboim I, Biran Y, Chaiseha S, et al (2004): The effect of a green and blue monochromatic light combination on broiler growth and development. Poult Sci, 83, 842-845.

41. Saari JC (2012): Vitamin A Metabolism in Rod and Cone Visual Cycles. Annu Rev Nutr, 32, 125-45.

42. Shen S-T, Yu JY-L (2002): Cloning and gene expression of a cDNA for the chicken follicle-stimulating hormone (FSH)- $\beta$-subunit. Gen Comp Endocrinol, 125, 375-386.

43. Singh R, Cheng K, Silversides F (2009): Production performance and egg quality of four strains of laying hens kept in conventional cages and floor pens. Poult Sci, 88, 256-264.

44. Sparks N (2006): The hen's egg-is its role in human nutrition changing? World Poultry Sci J, 62, 308-315.

45. Tabeekh MAA (2016): The effect of color light and stocking density on some enzymes and hormones of broilers and layers. Res Zool, 6, 21-28.

46. Tostivint H (2011): Evolution of the gonadotropinreleasing hormone (GnRH) gene family in relation to vertebrate tetraploidizations. Gen Comp Endocrinol, 170, 575-581.

47. Wang Y, Ding J, Yang H, et al (2015): The effect of new monochromatic light regimes on egg production and expression of the circadian gene BMAL1 in pigeons. Poult Sci, 94, 836-840.

48. Yang Y, Yu Y, Pan J, et al (2016): A new method to manipulate broiler chicken growth and metabolism: Response to mixed LED light system. Sci Rep, 6, 1-10.

49. Yuan J, Guo Y, Yang Y, et al (2007): Characterization of fatty acid digestion of Beijing fatty and arbor acres chickens. Asian-Austral J Anim Sci, 20, 1222-1228. 